\title{
Design and Construction of a Tube Storage Device for Biogas Using Motorized Compressor
}

\author{
Ikpi Azwis Nyifi", Simon Verlumun Irtwange, Tanko Bako \\ Department of Agricultural and Environmental Engineering, University of Agriculture, Makurdi, Nigeria
}

Email address:

inyifi@gmail.com (I. A. Nyifi)

${ }^{*}$ Corresponding author

\section{To citethisarticle:}

Ikpi Azwis Nyifi, Simon Verlumun Irtwange, Tanko Bako. Design and Construction of a Tube Storage Device for Biogas Using Motorized Compressor. International Journal of Science and Qualitative Analysis. Vol. 4, No. 1, 2018, pp. 20-26. doi: 10.11648/j.ijsqa.20180401.14

Received: December 21, 2017; Accepted: January 16, 2018; Published: February 5, 2018

\begin{abstract}
Biogas refers to a gas produced by break down of organic matter in the absence of oxygen. Organic waste such as dead plant and animal material, animal faeces and kitchen waste can be converted into a gaseous fuel called biogas. Usually, getting rid of waste places burden of not only cost on organizations, communities, government among others but also engender several environmental issues. The objective of this study was to design and develop a simple technique for handling and storing of biogas, analyze the biogas produced by the mixture of cow dung, and finally test the biogas produced to confirm its flammability. In this work, waste material specifically cow dung was used for the production of biogas in biogas digester at the animal farm of the University of Agriculture, Makurdi. The waste materials fed into the digester were cow dung and water to mix wastes into slurry. The mixture was done in the ratio of 1 to 2 by mass; cow dung to water respectively. The storage device was filled up with biogas by using a motorized compressor. The system was tested at retention times of 15, 20 and 25 days and gas burning times of 20,40 and 60 minutes. The effects of heating time and retention time on gas volume and pressure were analyzed. It was observed that the gas volume utilized increased with increasing heating time at all the retention times investigated. Finally, analysis of the biogas thus produced were studied and compared to previous work. The biogas produced in this work was indeed flammable and at a relatively low cost. Production of biogas at optimal conditions was recommended as a panacea to solving the prevalent environmental issues caused by waste disposal; and should be embraced not only by government on a large scale but also by individual on smaller scale.
\end{abstract}

Keywords: Biogas, Tube Storage, Device, Gas Pressure, Motorized Compressor

\section{Introduction}

Biogas is a flammable mixture of different gases that is produced by decomposition of biodegradable organic matters by micro-organisms in absence of oxygen. Biogas is produced by anaerobic digestion of biological wastes, animal droppings, municipal solid waste, industrial wastewater, and landfill [1, 2]. According to Itodo [3], the biodegradation of organic matter by anaerobic bacteria, which occurs in a digester plant, produces methane (40-70\%), Carbondioxide (30-60\%), hydrogen (0-1\%) and hydrogen sulphide (0-3\%). Although there are factors such as temperature, composition of feedstock, $\mathrm{pH}$, toxicity, loading rate, retention time, availability of micro-organisms, mixing which affects production of biogas.
Adelekan and Bomgboye [4] reported that biogas is an alternative and a renewable energy source produced through the anaerobic (oxygen free) digestion (AD) of organic matters where by the organic matter is converted to a combustible biogas, rich in methane $(\mathrm{CH} 4)$ and a liquid effluent. It is the methane components of biogas that will burn to produce energy. The effluent can be stored in a tank and later be applied to the land at appropriate time as a fertilizer without further treatment. On the other hand, the effluent can be separated into solid (fibre) and liquid [2]. The solid can be composted prior to sale for use as compost or animal beddings. The liquid which still contains nutrients can be sold or used on the farm as a liquid fertilizer as part of crop nutrient management plan $[5,6]$.

Biogas can be produced in a small scale for household use, mainly for cooking and heating or on large industrial scale, 
where it can be either be burnt in power generation devices for on-site generation or upgraded to natural gas standards for injection into the natural gas network as bio-methane or for use as gaseous bio-fuel in gas engine-base captive fleets such as buses. Biogas is not typically produced at the time or in the quantity needed to satisfy its usefulness. When this occurs, storage systems are employed to smooth out variations in gas production, gas quality and gas consumption $[7,8]$.

A wide variety of materials have been used in making biogas vessels are usually constructed of mild steel while low-pressure storage vessels can be made of steel, concrete, plastics, fibre glass, flexible fabrics or rubbers. Each material possesses advantages and disadvantages that the system designer must consider. The newest reinforced plastic features polyester fabric which appears to be suitable for flexible digester cover. The storage component also acts as a reservoir, allowing downstream equipments to operate at a constant pressure. The delivery pressure required for the final biogas conversion system affects the choice for biogas storage [8, 9 and 10].

Biogas production with small digester plant may not be steady and low pressure makes it impossible for use outside the site of production thereby restricting the use at the production site; there are rising needs of biogas for cooking and heating in other places.

It is against this backdrops that the study on "Design and Construction of Tube Storage Device for Biogas Using a Motorized Compressor" became necessary to take biogas from the production site to elsewhere and use for cooking and heating purposes thus making biogas available and accessible in places of demand.

\section{Literature Review}

\subsection{Biogas}

Biogas typically refers to a gas produced by the breakdown of organic matter in the absence of oxygen. It is a renewable energy source. Furthermore, biogas can be produced from regionally available raw materials such as recycled waste and is environmentally friendly. A biogas digester, also known as a methane digester, is a piece of equipment that can turn organic waste into usable fuel [10]. In addition to providing a source of renewable fuel, biogas digesters also provide low-cost fuel to people in poverty, and help to use waste materials effectively, which would otherwise be discarded.

The biogas digester relies on bacterial decomposition of biomass-waste material which is biological in origin, ranging from kitchen scraps to cow dung. The main part of a biogas system is a large tank, or digester. Inside this tank, bacteria convert organic waste into methane gas through the process of AD. Each day, the operator of a biogas system feeds the digester with household by-products such as market waste, kitchen waste, and manure from livestock. The methane gas produced in a biogas system may be used for cooking, lighting, and other energy needs. Waste that has been fully digested exits the biogas system in the form of organic fertilizer. New technologies in the field of biogas digesters include bag-type biogas digester plants, Vacvina biogas digester, and plastic-drum type biogas digesters [11].

\subsection{Historical Development in Biogas Digesters}

Biogas utilization from anaerobic digestion (AD) appears to have a long history. Evidence suggests that biogas was used even 3000 years ago for heating bath water in Assyria. As reported by Marco Polo, the ancient Chinese literature mentions covered sewage tanks built for biogas production some 2000-3000 years ago [12].

The technology of biogas production dates back to a long time. In the seventeenth century, Jan Baptita Van Helmont first determined that flammable gases could develop from putrefying organic matter. In 1776, Count Alessandro Volta suggested that there was a direct relation between the quantity of decomposing organic matter and the quantity of flammable gas generated. In 1808, Sir Humphry Davy determined that methane exists in the gases generated during the AD of cattle dung [12].

In 1859, the first sewage plant in modern times was built in Bombay. In 1895 this concept was brought to the UK. The gas produced was used to light street lamps. The arrangement was developed in the UK and Germany in the early 1900s for the management of sewage. The gas produced was sometimes used as a source of energy, especially during the Second World War. Since then, a number of sewage plants drove vehicles on biogas.

In the 1930s, the use of farm manure to generate methane was again developed in Bombay. Only in the early 1960s, it was developed for utilization by Indian villagers by the Khadi and Villages Industries Commission (KVIC). The design used a floating gas steel drum and formed the basis of an ongoing Indian Government program to reach out to villagers for providing them with fuel for cooking [9]. In India, a lot of important work on biogas has been done. But only in more recent times did these developments reach the other parts of the world when almost every nation became attracted to the subject. In India since 1939, research on biogas was undertaken but it was not until 1951 that there was a real start in its use. However, the developments of biogas plants were still slow and unsatisfactory until 1961 when the Indian Khadi and Village Industries Commission took over.

About 7000 biogas plants had already been installed by 1973-1974, and the number more than doubled by 19741975. The development in the design, construction, and operation of practical digesters was one reason for this increase in the number of biogas plants. Additionally, enough knowledge was obtained for the utilization of the gas not only for cooking but also for lighting and running engines. The involvement of competent scientists can also be attributed for the success.

The wide-ranging work on biogas in India may be classified into three stages: experimentation, 1937-1950; 
pilot studies, 1950-1963; and fully operational stage, from 1964 [13]. In 2007, there were 26.5 million biogas plants in China. Meanwhile, in 1999 there were over three million family-sized biogas plants in India. By the end of 2007, the Indian government had given subsidy for construction of nearly four million family-sized biogas plants. Since 19811982, the National Project on Biogas Development (NPBD) has run and promotes its own digester designs while providing monetary support and different training and development programs. Subsidies from the State and Central governments to install household bioreactors ranged from 30 to $100 \%$ in the $1980 \mathrm{~s}-1990 \mathrm{~s}$ [8].

\subsection{Digestion Factors}

Anaerobic digestion depends on several different parameters for an optimum performance. Different groups of microorganisms are involved in the methane production, and suitable conditions have to be established to keep all the microorganisms in balance. Some of these parameters are: $\mathrm{pH}$, temperature, mixing, substrate, $\mathrm{C} / \mathrm{N}$ ratio, and hydraulic retention time (HRT). Digestion is a slow process and it takes at a minimum of three weeks for the microorganisms to adapt to a new condition when there is a change in substrate or temperature [14]. A symbiotic relationship is necessary between the hydrogen-producing acetogenic microorganisms and the hydrogen-consuming methanogens. Furthermore, a neutral $\mathrm{pH}$ is favorable for biogas production, since most of the methanogens grow at the $\mathrm{pH}$ range of $6.7-$ 7.5. Temperature is also an important factor in the biogas production. Most of the acid forming microorganisms grows under mesophilic conditions; however, for methanogens, a higher temperature is favorable [14].

Mixing is also an essential parameter for biogas production. Too much mixing stresses the microorganisms and without mixing foaming occurs. Methane-forming microorganisms grow slowly, with a doubling time of around 5-16 days. Therefore, the hydraulic retention time should be at least 10-15 days, unless these bacteria are retained by, for example, entrapment. Substrate and the balance of carbon sources with other nutrients such as nitrogen, phosphorus, and sulfur is also important.

The substrate should be slowly digested; otherwise easily degradable substrates may cause a sudden increase in acid content. The carbon and nitrogen ratio should be around $16: 1-25: 1$. Too much increase or decrease in the carbon/nitrogen ratio affects biogas production. The concentration of solids in the digester should vary between $7 \%$ and $9 \%$. Particle size is not an important factor compared to other parameters such as $\mathrm{pH}$ and temperature. However, the size of the particles used affects the degradation and ultimately the biogas production rate [15].

\subsection{Biogas Storage and Maintenance of Digesters}

Storing the biogas produced is often a major concern. Biogas can be transported directly to the kitchen or stored in a pressurized tank, floating drum storage, gas cylinders, and gasbags. Storing the biogas reduces the problem of low flow rate during cooking. Biogas can be transported from one place to another by using gasbags. The excess pressure in the storage container can be released using a ' $\mathrm{T}$ ' shaped valve [9].

The amount of biogas produced in the digester depends on the material fed, type of the material, Carbon/Nitrogen ratio, digestion time, and temperature. For instance, highly concentrated influent slows down the fermentation, and diluted influent causes scum formation. To keep the solids concentration, the amount of water and biomass added should be in equal proportion. The digester should be fed every day. However, free fermentable carbohydrates will increase the volatile fatty acids concentration, which affects the methane forming bacteria. Usually, the steady state of biogas production is observed after two months of operation with a constant organic loading rate $[9,10]$.

\section{Materials and Methods}

\subsection{Description of the Biogas Plant}

Figure 1 is the photograph of the biogas plant. It has the capacity of $3 \mathrm{~m}^{3}$ and has a fermentation well of $120 \mathrm{~cm}$ inner diameter and $150 \mathrm{~cm}$ height. The well of the digester is plastered with cement and the base made with concrete to avoid underground water entering into the digester and to avoid seepage of water into the digester. The influent chamber is made of $55 \mathrm{~cm} \times 45 \mathrm{~cm}$ box with a pipe of $23 \mathrm{~cm}$ diameter, which opens into the well at about $70 \mathrm{~cm}$ from the bottom of the well and inclined at an angle of 300 from the vertical. The affluent chamber is of $62 \mathrm{~cm} \times 38 \mathrm{~cm}$ box and a pipe of $20 \mathrm{~cm}$ diameter opens into the well at about $90 \mathrm{~cm}$ from the bottom of the well and inclined at an angle of 450 from the vertical.

Water jacket seat directly above the well, which consist of two concentric rings. The outer ring of the plant is $140 \mathrm{~cm}$ diameter, $55 \mathrm{~cm}$ high and $10 \mathrm{~cm}$ thick and the inner ring is of $100 \mathrm{~cm}$ diameter, $50 \mathrm{~cm}$ high and $10 \mathrm{~cm}$ thick. The base and the wells of the water jacket are plaster to avoid any form of leakages. A steel gasholder of $112 \mathrm{~cm}$ diameter, $50 \mathrm{~cm}$ high and with the thickness of $2.5 \mathrm{~mm}$ of a cone shape cover seats completely in the water jacket which floats in water as it collects displaced gas produced in the digester, depending on the quantity and pressure of gas it contains. The gasholder releases enriched methane gas through flexible hose to the compressor for storing in a tube for burning elsewhere.

\subsection{Description of the Storage Device}

Figure 2 is the isometric drawing of the biogas storage device while Figure 3 is the photograph pumping of Biogas into a Storage Device. It is a circular, hollowed and elastic material made of butyl rubber with outer and inner diameter of $1.4 \mathrm{~m}$ and $0.54 \mathrm{~m}$ respectively. It has a metallic outlet pipe made of brass material of outer diameter of $8 \mathrm{~mm}$, inner diameter of $3 \mathrm{~mm}$ and length of $150 \mathrm{~mm}$ fitted with a nonreturn pressure valve. The pipe is used to let in gas to the 
device from the compressor discharge line and to draw gas from the device for burning on biogas burner.

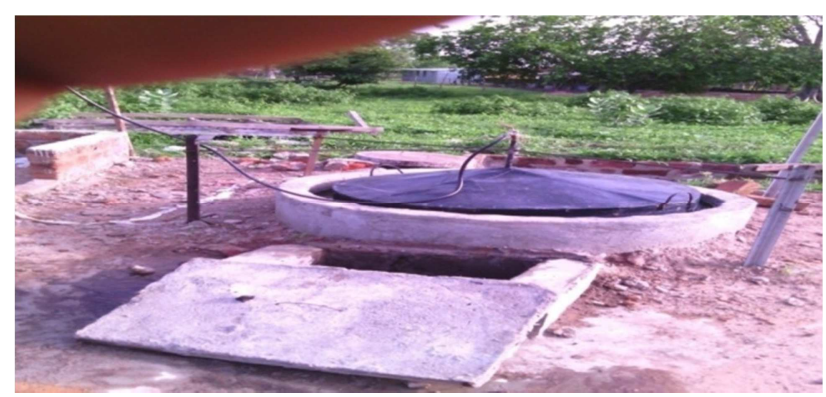

Figure 1. A $3 m^{3}$ floating drum continuous biogas plant.

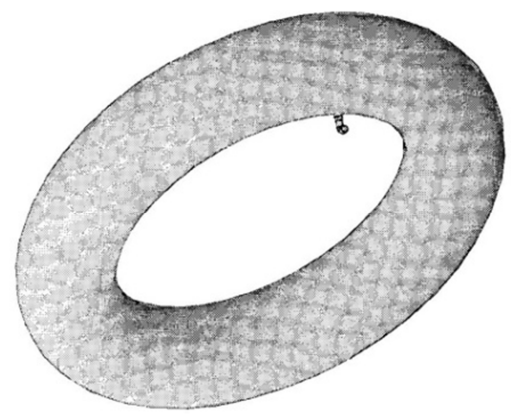

Figure 2. Isometric drawing of the gas tube storage device.

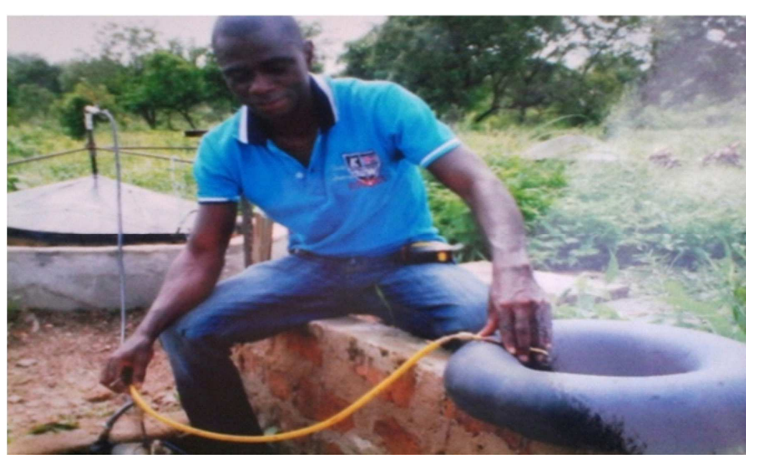

Figure 3. Pumping of biogas into a storage device.

\subsection{Design Analysis of the Tube Storage Device}

Design considerations of the gas storage device

The following were considered in the design of the storage device:

i. Inner tube of a truck of wall thickness of $2.5 \mathrm{~mm}$ was selected as the storage device because it is made of butyl rubber material which does not react with water vapour in the biogas that might cause corrosion and does not permit gas movement across its boundary of $2.5 \mathrm{~mm}$ unlike other synthetic rubbers and rubberized vinyl sheets,

ii. The inlet pipe of the inner tube is made of brass material which has proven to be resistant to reaction with biogas as Copper, aluminium and zinc are not resistant to biogas,

iii. PVC-U pipes are used as biogas carrying lines are resistant to biogas reaction and corrosion,

iv. A pressure valve was used because it does not permit back flow of gas as did control and check valves, which allow fluid to flow through them only in one direction.

Sizing of storage device

Storage device capacity (CT) was calculated from the Equation;

$$
C_{T}=\frac{V_{h}}{V_{g}}
$$

Where; $\mathrm{CT}=$ Storage Capacity, $\mathrm{Vh}=$ Volume of Storage Tube, $\mathrm{m}^{3}, \mathrm{Vg}=$ Volume of daily gas production, $\mathrm{m}^{3}$

Daily gas yield, $V_{g}=1.2 \mathrm{~m}^{3}=1200 \mathrm{~L}$

Gas production per hour $=\frac{1200 \mathrm{~L}}{24 \mathrm{~h}}=50 \mathrm{~L} / \mathrm{h}$

Gas production per $\min =\frac{50 \mathrm{~L}}{60 \mathrm{mins}}=0.83 \mathrm{~L}$

Time of gas compression $=4 \mathrm{mins}$.

Gas compression per $\min =1200 \times \frac{4}{60}=80 \mathrm{~L}$

The longest interval between periods of $8 \mathrm{mins}$ compression, the storage tube size

$$
V_{h}=50 \mathrm{~L} \times 8 \mathrm{mins}=400 \mathrm{~L}
$$

The maximum storage device size when applying safety margin of $25 \%$ is;

$$
V_{h}=400 \mathrm{~L} \times 1.25=600 \mathrm{~L} .
$$

The StorageCapacity, $C_{T}=\frac{600 L}{1200 L}=0.5=50 \%$

Storage device of $0.6 \mathrm{~m}^{3}$ was designed.

Compression ratio

Compression Ratio of the compressor was calculated from the Equation;

$$
\text { Compression ratio, } R=\frac{P_{d}}{P_{S}}
$$

Where, $\mathrm{P}_{\mathrm{S}}=$ suction pressure and $\mathrm{P}_{\mathrm{d}}=$ discharged pressure Volumetric efficiency

Volumetric Efficiency was calculated from the Equation; Volumetric Efficiency,

$$
\mathrm{VE}=93-R-8\left(R \frac{1}{n-1}\right)
$$

Where; $\mathrm{R}=$ Compression ratio, $\mathrm{n}=$ Specific heat ratio of gas Determination of volume of the gasholder

Total volume of gas in gasholder,

$$
\mathrm{V}_{\mathrm{t}}=\mathrm{Vg}+\mathrm{Vh}+\mathrm{Vc}
$$

Where; $\mathrm{Vg}=$ Volume of gasholder, $\mathrm{Vh}=$ Volume of headspace, $\mathrm{Vc}=$ Volume of gasholder cone cap

The volume of gas contained in gasholder cylinder at a given time was calculated from the Equation;

$$
\text { Volume of a Cylinder, } V=\pi r^{2} h
$$

Where, $\mathrm{V}=$ Volume of cylinder, $\mathrm{m}^{3}, \mathrm{r}=$ Radius of cylinder, and $\mathrm{h}=$ Height of cylinder, $\mathrm{m}$

The volume of cone cap of gasholder, 


$$
\mathrm{V}=\frac{\pi \mathrm{r}^{2} \mathrm{~h}}{3}
$$

\subsection{Determination of Amount of Biogas in Storage Device}

The gas in the storage device is regarded as incompressible because the pressure in it is less than lbar (maximum is 0.28 bar), as such perfect gas equation cannot be employed here for a compressed gas [16]. Therefore, the volume of the gas in the storage tube is taken to be equivalent to the volume of the inflated tube, which is a hollow circular cylinder and can be computed using the Equation;

Volume of hollowed circular cylinder,

$$
V=2 \pi R A
$$

Where, $\mathrm{A}=$ Area of a Circle, $\mathrm{m} 2=\boldsymbol{\pi} r^{2}, \mathrm{R}=$ Radius of Circular Tube to centre cross-section and $r=$ Cross-Section Radius.

\subsection{Selection, Preparation and Pre-Treatment of Test Materials}

Fresh cattle dung and a $3 \mathrm{~m}^{3}$ continuous floating drum biogas plant at Teaching and Research Farm, University of Agriculture, Makurdi were used to produce biogas for storage in the storage device. Piping work was done on the plant to allow for gas delivery to the compressor and to the storage device. The plant was loaded with $730 \mathrm{~kg}$ of cattle dung and $1490 \mathrm{~kg}$ of water giving a ratio of 1: 2 for retention period of 30 days. After 15 days of loading, the plant was recharged with fresh slurry at every 5 days interval with $200 \mathrm{~kg}, 150 \mathrm{~kg}$ and $120 \mathrm{~kg}$ of slurry respectively with ratio of cattle dung to water of $1: 2$.

\subsection{Experimental Procedure}

A pipe with a control valve was used to connect gasholder to the inlet pipe of the compressor, another pipe from the compressor discharge outlet to the storage device and fitted with a non-return pressure valve. The compressor was connected to a power source (Climax SH2900 Generator: AC-220V, DC-12V, $8.3 \mathrm{~A}, 5.5 \mathrm{Hp}$ and $2.00 \mathrm{kVA}$ ). The gas in the gasholder was pumped into storage device for total time of 4 minutes and the pumping of gas was stopped after 2 minutes and continues again for 2 minutes to avoid heat of compression until the gas in the gasholder was completely pumped into the device. The gas in the storage device was tested on UAM biogas stove by heating at the time interval of 20,40 and 60 minutes respectively. Pressure was measured using pressure guage.

\subsection{Determination of Volume of Biogas in the Storage Device}

The quantity of biogas in the storage device was determined using Equation 7.

\subsection{Determination of Storage Utilization of the Storage Device}

The percentage utilization of biogas in a storage device was calculated using the Equation as has been presented by Paul [17].

$$
U_{s=} \frac{W_{d}}{W_{f}} X 100 \%
$$

Where,

$\mathrm{W}_{\mathrm{d}}=$ Amount of Gas Dispensed, $\mathrm{m}^{3}$

$\mathrm{W}_{\mathrm{f}}=$ Amount of Gas Stored, $\mathrm{m}^{3}$

$$
U_{s}=\frac{0.91 m^{3}}{1.17 m^{3}} X 100 \%=77.8 \%
$$

\subsection{Experimental Design and Statistical Analysis}

The experimental design for the statistical analysis follows a two-treatment effects (heating time and retention time) in a split-plot factorial design with Completely Randomized Design (CRD) involving a two-way classification with three observations (replications) per experimental unit comprising of two factors; three heating times (20, 40 and 60mins) in each of the three levels of retention times $(15,20$ and 25 days) giving nine treatment combinations and twenty seven observations for the experiment as heating time versus retention time. The heating time in the combination forms the level of factor 'A', while the retention time forms the level of factor ' $B$ '. All data collected in were subjected to Analysis of Variance (ANOVA) to test for significant effects at 95\% confidence limit. When significant differences were observed, treatment means were separated using F-LSD.

\section{Results and Discussions}

\subsection{Results}

The analysis of variance (ANOVA) at $\mathrm{P} \leq 0.05$ of the effects of heating time and retention time on gas volume is presented in Table 1 and the Means using F-LSD is presented in table 2. Moreover, Figure 4 shows the effects of heating time and retention time on the mean gas volume.

The analysis of variance (ANOVA) at $\mathrm{P} \leq 0.05$ of the effects of heating time and retention time on gas pressure is presented in Table 3 and the Means using F-LSD is presented in table 4. Moreover, Figure 5 shows the effects of heating time and retention time on the mean gas pressure.

Table 1. Analysis of variance (ANOVA) of effects of heating time (mins) and retention time (days) on gas volume $\left(\mathrm{m}^{3}\right)$.

\begin{tabular}{llllll}
\hline Sources of Variation & Df & SS & MS & F-cal & F-tab (5\%) \\
\hline Heating Time (A) & 2 & 0.0037 & 0.00185 & $9.54 * 3.55$ \\
Retention Time (B) & 2 & 0.0030 & 0.00150 & $7.73 * 3.55$ \\
Interaction (AB) & 4 & 0.0030 & 0.00075 & $3.87 * 2.93$ \\
Error & 18 & 0.0035 & 0.000194 & & \\
Treatment Combinations & 8 & 0.0099 & & & \\
Total & 26 & 0.0134 & & & \\
\hline
\end{tabular}

$*$ =Significant. 
Table 2. Effects of heating time (mins) and retention time (days) on mean gas volume $\left(\mathrm{m}^{3}\right)$.

\begin{tabular}{llll}
\hline Retention Time (days) & \multicolumn{3}{l}{ Heating Time (mins) } \\
\hline & $\mathbf{2 0}$ & $\mathbf{4 0}$ & $\mathbf{6 0}$ \\
\hline 15 & 0.09 & 0.10 & 0.12 \\
20 & 0.08 & 0.09 & 0.10 \\
25 & 0.10 & 0.11 & 0.12 \\
\hline
\end{tabular}

F-LSD $0.05=0.014$, for comparing two treatment combination means.

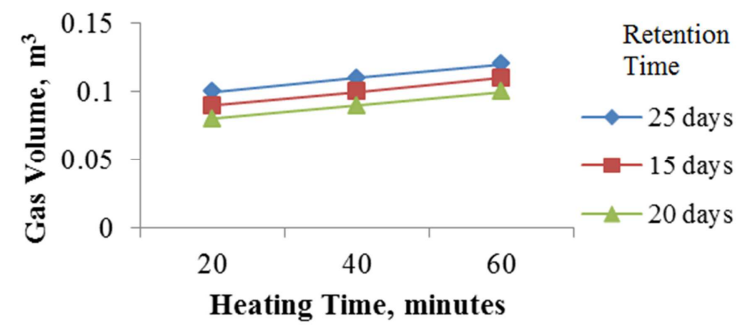

Figure 4. Effects of retention time (days) and heating time (mins) on mean gas volume $\left(\mathrm{m}^{3}\right)$.

Table 3. Analysis of variance (ANOVA) of effects heating time (mins) and retention time (days) on gas pressure (kpa).

\begin{tabular}{llllll}
\hline Source of Variance & df & SS & MS & F-cal & F-tab (5\%) \\
\hline Heating Time (A) & 2 & 552.00 & 276.00 & $43.615^{*}$ & 3.55 \\
Retention Time (B) & 2 & 27.63 & 13.815 & $2.299^{\text {ns }}$ & 3.55 \\
Interaction (AB) & 4 & 27.63 & 6.9075 & $1.145^{\text {ns }}$ & 2.93 \\
Error & 18 & 108.59 & 6.0328 & & \\
Treatment Combinations & 8 & 618.54 & & & \\
Total & 26 & 727.13 & & & \\
\hline
\end{tabular}

$*$ Significant ${ }^{\mathrm{ns}}=$ Not Significant.

Table 4. Effects of heating time (mins) and retention time (days) on mean gas pressure $(\mathrm{kPa})$.

\begin{tabular}{llll}
\hline Retention Time (days) & \multicolumn{3}{l}{ Heating Time (mins) } \\
\hline & $\mathbf{2 0}$ & $\mathbf{4 0}$ & $\mathbf{6 0}$ \\
\hline 15 & 16.33 & 12.60 & 4.40 \\
20 & 16.30 & 12.63 & 6.43 \\
25 & 19.33 & 12.87 & 5.30 \\
\hline
\end{tabular}

F-LSD ${ }_{0.05}=2.43$, for comparing two treatment combination means.

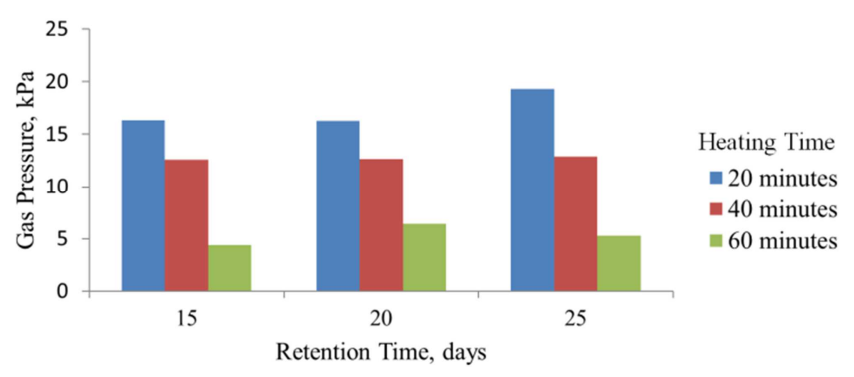

Figure 5. Effects of retention time (days) and heating time (mins) on mean gas pressure $(\mathrm{kPa})$.

\subsection{Discussions}

According to Rajendran et al. [9], hydraulic retention times (HRT) vary between 20 and 100 days for mesophilic household digesters. Studies show that decreasing HRT from 90 days to 60 day and increasing the ordinary loading rate by diluting the substrate from 1:4 to 1:2 would be beneficial for the better performance of the digester. Many household digesters do not have a stirrer to mix the digester content, which creates stagnant regions in the digesters. Due to these stagnant regions, the digester HRT is decreased compared to its calculated HRT, leading to wash out of the microorganisms.

Ganiyu and Samuel [18] investigated the effect of plantain peels as co-substrate in the anaerobic digestion of cow dung for efficient and high biogas production. The biogas experiments were carried out in two different $5 \mathrm{~L}$ anaerobic digesters and incubated for 40 days at ambient mesophilic temperatures $\left(28^{\circ} \mathrm{C}\right.$ to $\left.34^{\circ} \mathrm{C}\right)$. The results showed that codigestion of cow dung with plantain peels as co-substrate reduced start-up time for biogas generation and increased biogas yield by $18 \%$ as compared to cow dung alone. Peak biogas production was obtained for both digesters at $\mathrm{pH}$ of 6.7 and 6.9 as well as temperature of 29 and $30^{\circ} \mathrm{C}$, respectively. The study shows that the cumulative biogas production increased with increased in hydraulic retention time and started to decrease after day 30 in both digesters.

The biogas produced from the experiment showed the good quality combustible biogas yield. From the ANOVA (Table 1) there is a significant difference in the heating time, retention time and their interaction. There was significant difference in the gas volume at all the retention times investigated for 20 minutes and 60 minutes heating times. The highest gas volume $\left(0.12 \mathrm{~m}^{3}\right)$ was obtained for heating time of 60 minutes and retention time of 25 days. The lowest gas volume $\left(0.08 \mathrm{~m}^{3}\right)$ was obtained for the conditions of 20 minutes heating time and 20 days retention time. It was observed from table 2 that the gas volume utilized increased with increasing heating time at all the retention times investigated. This is in agreement with the work of Ganiyu and Samuel [18].

From the ANOVA (Table 3) there is a significant difference in the heating time, but there was no significant difference in the retention time and there interaction. From the means separation (Table 4), there was significant difference in the gas pressure at all the heating times investigated for the entire retention times. The highest gas pressure $(19.33 \mathrm{kPa})$ was obtained for heating time of 20 minutes and retention time of 25 days. The lowest gas pressure $(4.40 \mathrm{kPa})$ was obtained for the conditions of 60 minutes heating time and 15 days retention time. It was observed from table 4 that the gas pressure decreased with increasing heating time at all the retention times investigated.

\section{Conclusion and Recommendations}

\subsection{Conclusion}

The result of this research on the production and storage of biogas in a vehicle tube has shown that flammable biogas can be produced from cow dung through anaerobic digestion and stores in a portable tube for biogas energy generation. This waste is always available in our environment and can be used as a source of fuel if managed properly. The study revealed 
further that animal waste has great potentials for generation of biogas and its use should be encourage due to its early retention time and high volume of biogas yields. It is pertinent to provide appropriate mixing ratio and other optimal conditions to help ensure that adequate and good quality biogas is engendered. Also in this study, it has been found that hydraulic retention time affected the volume yield of biogas production.

The study of tube storage of biogas concluded that $0.41 \mathrm{~m}^{3}$ was effectively stored in storage device of $0.6 \mathrm{~m}^{3}$ capacity (600 Litres). Results of performance evaluation of storage device showed that gas volume utilised increased with increasing heating time at all the retention times investigated and the gas pressure decreased with increasing heating time at all the retention times investigated.

\subsection{Recommendations}

The cow dung waste and other materials which can decompose should be used for the production of biogas, the wastes should not be too solid or watery, and it should be in a slurry form and be mixed in the ratio of 1 to 2 (cow dung to water) by mass. It is also recommended that truck inner tube of $12.00 \times 20$ be used for storing $0.41 \mathrm{~m}^{3}$ of biogas at a pressure of $28 \mathrm{kPa}$ for cooking outside the place of production. It is also suggested that in further study, the elastic limit of inner tube be determined before storing maximum amount of biogas to avoid rupture.

\section{References}

[1] Agbo, K. E., and Eze, J. I. (2011). Anaerobic Digestion of Municipal Solid for Generation of Energy: Prospects and Challenges in Nigeria. Nigerian Journal of Solar Energy Research, 22, 120-136.

[2] Hassan, K. J., Zubairu, M. S. and Husaini, I. (2015). Biogas Production Using Cow Dung, Poultry Waste and Yam Peels. International Journal of Environment and Bioenergy, 2015, 10(2): 107-114.

[3] Itodo, N. I. (2007). Agricultural Energy Technology. Makurdi: Aboki Publishers, Pp. 1-108.

[4] Adelekan, B. A., and Bomgboye, A. I. (2008). Effect of Mixing Ratio of Slurry on Biogas Productivity of Major Farm Animal Waste Types. Journal of Applied Sciences, 22, 1336 1343.

[5] Ogejo, J. A., and Ignosh, J. (2009). Biomethane Technology. Petersburg: Virgini Polytechnic, Institute and State University, Pp 442-881.
[6] Gazali, T. A. and Moqsud, M. A. (2017). The Effectiveness of Animal Dungs and Leaf Mold for Bioelectricity Generation Using Microbial Fuel Cell with Soils. Journal of Sustainable Bioenergy Systems, (7): 165-181.

[7] Meng, W., Eunyoung, L., Qiong, Z. and Sarina, J. E. (2017). Anaerobic Co-digestion of Swine Manure and Microalgae Chlorella sp.: Experimental Studies and Energy Analysis. BioEnergy Research, 9 (4): 1204-1215.

[8] Peter, T., Clever, K., Jerekias, G. and Noble, B. (2016). Effect of Variation in Co-Digestion Ratios of Matooke, Cassava and Sweet Potato Peels on Hydraulic Retention Time, Methane Yield and Its Kinetics. Journal of Sustainable Bioenergy Systems, 6: 93-115.

[9] Rajendran, K., Aslanzadeh, S., and Taherzadeh, M. J. (2012). Household biogas Digesters-A review. Energies, 5(8): 29112942.

[10] Bansal, A. K., Kapoor, S., and Agrawal, M. K. (2013). The road to zero waste: anaerobic digestor. International Journal of Environmental Sciences, 3(5), 1390-1397.

[11] Bavutti, M., Guidetti, L., Allesina, G., Libbra, A., Muscio, A., and Pedrazzi, S. (2014). Thermal stabilization of digester of biogas plants by means of optimization of the surface radiative properties of the gasometer domes. Energy Procedia, 45, 1344-1353.

[12] Bond, T., and Templeton, M. R. (2011). History and future of domestic biogas plants in the developing world. Energy for Sustainable Development, 15, 347-354.

[13] Cuellar, A. D., and Webber, M. E. (2008). Cow power: the energy and emissions benefits of converting manure to biogas. Environmental Research Letters, 3, 1-8.

[14] Green, J. M., and Sibisi, M. N. T. (2002). Domestic Biogas Digesters: A Comparative Study. In Proceedings of Domestic Use of Energy Conference, Cape Town, South Africa, 2-3, April, 2002; pp. 33-38.

[15] Jiang, X., Sommer, S. G., and Christensen, K. V. (2011). A review of the biogas industry in China. Energy Policy, 39, 6073-6081.

[16] Cliffort, M., Brooks, R., Howe, A., Kennedy, A., McWilliam, S., Pickering, S., Shayler, P., and Shipway, P. (2011). Introduction to Mechanical Engineering, first edition (Pp. 140258). UK: Hodder Education 56 Hachjette.

[17] Paul, C. H. (2001). Compressor Handbook. New York: McGraw-Hill Company Inc.

[18] Ganiyu, K. L. and Samuel, E. A. (2015). Modelling the Kinetics of Biogas Production from Mesophilic Anaerobic Co-Digestion of Cow Dung with Plantain Peels. International Journal of Renewable Energy Development, 4(1), 55-63. 